論文

\title{
CMPO 含浸吸着材による高レベル放射性廃液核種分離システム
}

\author{
菊池 孝浩 $1, *, \uparrow ，$ 後藤 一郎 ${ }^{1}$, 新井 剛 ${ }^{1}$, 鈴木 和則 ${ }^{1}$
}

\author{
Separation System for HLLW by Using CMPO Impregnated Silica Adsorbent \\ Takahiro KIKUCHI ${ }^{1, *, \dagger}$, Ichiro GOTO ${ }^{1}$, Tsuyoshi ARAI ${ }^{1}$ and Kazunori SUZUKI ${ }^{1}$ \\ ${ }^{1}$ Institute of Research and Innovation (IRI), 1201 Takada, Kashiwa-shi, Chiba 277-0861, Japan
}

(Received August 25, 2006 and accepted in revised form January 29, 2007)**

\begin{abstract}
The process concept of separation system of high-level radioactive liquid waste (HLLW) using an octylphenyl- $N, N$-diisobutylcarbomoyl phosphine oxide impregnated silica adsorbent (CMPO-adsorbent) was designed for separation of $\mathrm{Cs}$ and $\mathrm{Sr}$. The process consists of two separation steps. Each step is composed of three CMPO-adsorbent columns, and the adsorbents are used in rotation for separation of HLLW. That is, the system has six columns. Uranium and Zirconium inhibit the adsorption of minor actinoids (MA) and lanthanoids. Therefore, the adsorption and removal of $U$ and $\mathrm{Zr}$ from the HLLW occur in the 1st step. Adsorbed $\mathrm{U}$ and $\mathrm{Zr}$ are eluted using citric acid. The HLLW from the 1 st step is sent to the 2 nd step to adsorb MA, lanthanoids and other transition metals. MA and lanthanoids are eluted using $0.01 \mathrm{~mol} / \mathrm{dm}^{3} \mathrm{HNO}_{3}$, and Mo is recovered by using oxalic acid. The process required a large amount of citric acid and oxalic acid, but these eluents can be reused, therefore the amounts of spent acids are reduced. The column adopted a cartridge form in consideration of the exchange of adsorbent. The bed volume of the adsorbent is $0.67 \mathrm{~m}^{3} /$ column. The size of separation plant has $60 \mathrm{~m}$ length, $80 \mathrm{~m}$ breadth and $36 \mathrm{~m}$ height.
\end{abstract}

\section{KEYWORDS: CMPO impregnated silica adsorbent, high-level radio active liquid waste, sepa- ration system}

\section{I. 緒 言}

PUREX 再処理施設から発生する高レベル放射性廃液 (以下, HLLW) 中には, 多数の放射性核種や安定同位体 元素が共存しており, ${ }^{137} \mathrm{Cs},{ }^{90} \mathrm{Sr}$ 等の発熱性核種の崩壊発 熱量によりガラス固化体への廃棄物充填量が制約されてい る。これは, 固化体発熱温度を, ホウケイ酸ガラスの相転 移温度や結晶化温度より低くする必要があるためと, 固化 体冷却貯蔵や地層処分受け入れ時の崩壊発熱量に制限があ るためである。設計基準となるガラス固化体の埋設初期発 熱量は, 「我が国における高レベル放射性廃棄物地層処分 の技術的信頼性一地層処分研究開発第 2 次取りまと女一 分冊 2 地層処分の工学技術」によれば約 $350 \mathrm{~W} /$ 本とな っている1)。さらに, 白金族やMoは, ホウケイ酸ガラス への溶解量が低く分相の原因となるので2,3)，均質なガラ ス固化体製造のためにはそれらの充填量も制限を受ける。 また, 燃料の高燃焼度化等に伴い, 使用済核然料 (以下,

\footnotetext{
1 財産業創造研究所

* Corresponding author, E-mail: tkikuchi@iri.or.jp

†現在, 独日本原子力研究開発機構

**本論文は，「技術報告」として受理・審査された。
}

$\mathrm{SF})$ 中の長半減期元素である $\mathrm{Am}, \mathrm{Cm}$ 等のマイナーアク チノイド (MA) 元素やFP 元素の増加により, HLLW 化 学組成の多様化や発熱量の増大が予想される。例えば, 然 焼度 $45 \mathrm{GWd} / \mathrm{t}$ と $70 \mathrm{GWd} / \mathrm{t}$ の軽水炉燃料を, 燃料取り 出し 4 年後に再処理した場合の HLLW の発熱量を ORIGEN II 計算コードにより推算すると, 高燃焼度化により 約2.8倍大きくなる。Ohtsuka らは, 高レベル放射性廃棄 物中の核種を短半減期で高発熱性の $\mathrm{Cs} \cdot \mathrm{Sr}$ 元素を含む元 素群と長半減期の MA を含む元素群に大別し, それぞれ を高充填固化し，Cs·Sr 元素については100年程度の中間 貯蔵期間を設けることで, 処分空間を $47 \%$ 低減できると 報告している(燃焼度 $45 \mathrm{GWd} / \mathrm{t}$ の軽水炉燃料を, 燃料取 り出し 4 年で再処理した場合 $)^{4)}$ 。

Ohtsuka らの報告に基づき処分空間を低減するために, 筆者らは $\mathrm{Cs} \cdot \mathrm{Sr}$ を含む元素群を, MA を含む元素群と分 離する核種分離技術について調査し適用成立性を検討し た。核種分離技術としては溶媒抽出法である TRUEXSETFICS 法5,6)が報告されているが，HLLW 中の MAの 濃度は相対的に低いので, 溶媒抽出法に代わり抽出クロマ 卜分離法を適用すると, 発生する有機溶媒廃液量を大幅に 低減できる可能性があることが報告されている7 9)。筆者 


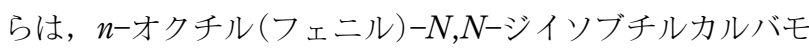
イルメチルフォスフィンオキサイド $(\mathrm{CMPO})$ をシリカ担 体に含浸した吸着材 (以下 CMPO 含浸吸着材)を用い, HLLW 中の短半減期発熱性核種 $(\mathrm{Cs}, \mathrm{Sr}$ 群) を中発熱性長 半減期核種 (MA • ランタノイド群) と分離できることを報 告した ${ }^{10 \sim 12)}$ 。さらに，筆者らは，CMPO 含浸吸着材中に 生成した放射線劣化物は, 溶離液中に溶出して吸着材中に 蓄積しないことを見い出した ${ }^{12)}$ 。このことから，溶媒抽 出法に抢いて，放射線劣化物を有機相から除去するために 必要となる, 大量のアルカリ洗浄液 ${ }^{13)}$ が発生しないと考 えられる。

この CMPO 含浸吸着材を適用した核種分離対象として 六ヶ所再処理工場 PUREX ラフィネート廃液を想定した 場合，吸着・溶離処理を年間数百回程度繰り返す必要があ ると考えられる。このため, 核種分離プロセスの成立性は, CMPO 含浸吸着材の初期分離性能ばかりでなく, 繰り返 し使用した場合の性能評価も重要となる。

本報では, CMPO 含浸吸着材を使用した吸着・溶離繰 り返し試験の結果 ${ }^{10,11)}$ および $\gamma$ 線照射試験の結果 ${ }^{10,12)} も$ とに，核種分離システム基本フローの構築およびプロセス 概念について検討した結果を報告する。

\section{II. 核種分離基本フロー}

燃焼度 $45 \mathrm{GWd} / \mathrm{t}$ の軽水炉燃料 $800 \mathrm{t}$ を, PUREX プロ セス年 200 日運転で再処理することを前提に，その PUREX ラフィネート廃液に対する CMPO 含浸吸着材によ る核種分離基本フローを構築した。PUREX ラフィネート 廃液量は，SF 溶解液量に相当すると仮定した場合，SF 溶解液中の U 濃度を $1 \mathrm{~mol} / \mathrm{dm}^{3}$ と考えると $3,300 \mathrm{~m}^{3} / \mathrm{y}$ に なる ${ }^{a)}$ 。この廃液化学組成を, 燃料取り出し後 4 年で再処 理した場合を想定して ORIGEN II 計算コードをもとに推 算した。なお，再処理工程から HLLWへのU, Puの移 行率は $0.1 \%$ 未満と予想されるが15), U と CMPO 含浸吸 着材との相互作用は大きく，分離プロセスに大きな影響を 及ぼすので，Uと Puが過剰に HLLW へ移行した場合を 考え移行率を $0.1 \%$ とした。また，Ruの70\%およびMoの

\footnotetext{
a) PUREX ラフィネート廃液量は, Barnwell の再処理工場の例 から SF 溶解液量より1.3倍程度多くなると思われるが14), 本 報では SF 溶解液量と同じと仮定した。PUREX ラフィネート 廃液量が増加すると, 高レベル放射性廃棄物 (HLW) 核種の濃 度は低下するので, 1 回当たりの処理廃液量は増えても, 処理 回数に変化はない 1 回当たりに処理できる廃液量は HLW 核 種に対する吸着容量で決まるが，液量増加が 1.3 倍程度であれ ば，液量の増加に伴う HLW 濃度の低下が吸着容量に及ぼす影 響は無視できるため)。処理廃液量が増えることで処理時間は 増加するが，吸着分離性能に対して HLLW 供給速度 (空間速 度)は余裕のある設定なので，処理液量の増加に伴う処理時間 の増加は HLLW 供給速度を変更することで対応可能である。 また, 現状では溶離液量が PUREX ラフィネート廃液量より 数倍多く, 処理時間の大半を溶離工程が占めている。よって, PUREX ラフィネート廃液量の増加に伴う影響は大きくないと 考えられる。
}

$50 \%$ は不溶解残渣に移行し HLLW には含まれないものと した。Zrについては $10 \%$ 程度不溶解残椬に移行すると思 われるが16), U 同様 CMPO 含浸吸着材との相互作用が大 きいので，不溶解残椬移行量は考慮せずに検討した。ま た，腐食生成物として Fe, Cr, Ni を考慮した。Table 1 に, SF を年 $800 \mathrm{t}$ 再処理した場合の HLLW 中に含まれる 元素の推定量を示す。

分離システムフローは Fig. 1 に示す。各カラムから溶 離される溶離液の処理を効果的に行うために, 濃縮機によ る溶離液濃縮処理を併用し, その濃縮能力に対応するため カラムも小型化し 3 塔並列にした。各カラムの吸着材充 填量は, 模擬 HLLW 吸着試験結果より求めた CMPO 含 浸吸着材の MA · ランタノイド吸着容量 (吸着材 $1 \mathrm{~m}^{3}$ 当た り約 $50 \mathrm{~mol}$ ) 等をもとに $0.67 \mathrm{~m}^{3}$ / 塔 (3 塔合計 $2 \mathrm{~m}^{3}$ ) とし た。これにより, 第 1 塔で吸着処理後この塔で溶離処理 を行いながら, 第 2 塔で吸着処理ができるので, 本来バ ッチ処理である吸着・溶離処理を連続的な処理にすること が可能である。また, 吸着元素回収の際, 吸着材に含浸し た CMPOの一部は溶離液中に溶解し溶出するので, 繰り 返し使用に伴い吸着容量が低下する。これを抑制するため に, 溶離液をあらかじめCMPO で飽和させておくことが 有効である。すなわち, 溶離液の供給ラインに CMPO 含 浸吸着材を充填した CMPO プレカラムを設置し, このプ レカラムに溶離液を通液して CMPO を飽和させ, 溶離処 理時の吸着塔カラムからの CMPO の溶解 · 溶出を抑制 し, 吸着容量を保持する10)。

HLLW 中の U, Zr は CMPO との相互作用が大きく, MA やランタノイドの吸着を阻害する。Figure 2 に, 吸

Table 1 Output of HLLW elements based on ORIGENII computer code

\begin{tabular}{|c|c|c|c|}
\hline Element & $\begin{array}{l}\text { Weight } \\
(\mathrm{kg} / \mathrm{y})\end{array}$ & Element & $\begin{array}{l}\text { Weight } \\
(\mathrm{kg} / \mathrm{y})\end{array}$ \\
\hline $\mathrm{U}$ & 754 & $\mathrm{Ru}$ & 715 \\
\hline $\mathrm{Np}$ & 542 & $\mathrm{Rh}$ & 454 \\
\hline $\mathrm{Pu}$ & 42 & $\mathrm{Pd}$ & 1,460 \\
\hline $\mathrm{Zr}$ & 5,374 & $\mathrm{Y}$ & 510 \\
\hline Sn & 92 & $\mathrm{Am}$ & 365 \\
\hline $\mathrm{Rb}$ & 387 & $\mathrm{Cm}$ & 33 \\
\hline $\mathrm{Sr}$ & 930 & $\mathrm{La}$ & 1,330 \\
\hline Cs & 2,800 & $\mathrm{Ce}$ & 2,596 \\
\hline $\mathrm{Ba}$ & 1,755 & $\operatorname{Pr}$ & 1,218 \\
\hline Mo & 1,822 & $\mathrm{Nd}$ & 4,405 \\
\hline $\mathrm{Ag}$ & 74 & $\mathrm{Pm}$ & 44 \\
\hline $\mathrm{Cd}$ & 118 & $\mathrm{Sm}$ & 800 \\
\hline $\mathrm{Sb}$ & 23 & $\mathrm{Eu}$ & 163 \\
\hline $\mathrm{Te}$ & 513 & $\mathrm{Gd}$ & 124 \\
\hline \multirow[t]{2}{*}{$\mathrm{Tc}$} & 812 & $\mathrm{Fe}$ & 4,800 \\
\hline & & $\begin{array}{l}\mathrm{Cr} \\
\mathrm{Ni}\end{array}$ & $\begin{array}{l}800 \\
760\end{array}$ \\
\hline
\end{tabular}




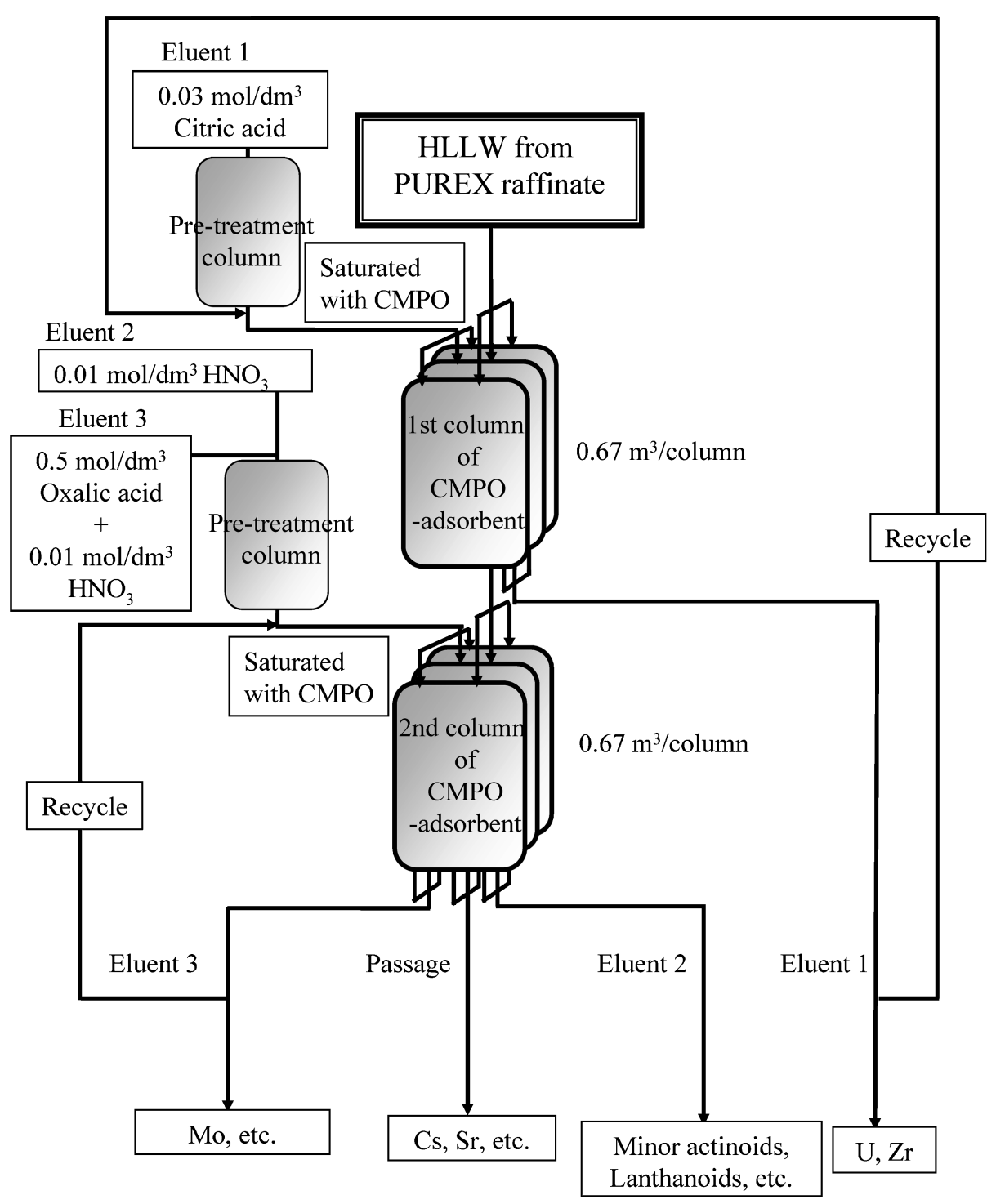

Fig. 1 Basic HLLW separation treatment process

着温度 $50^{\circ} \mathrm{C}$, 空間速度 $(\mathrm{SV})=2.5 / \mathrm{h}$ で模擬 $\mathrm{HLLW}$ 溶液を $\mathrm{CMPO}$ 含浸吸着材に通液したときの代表的な元素の破過 曲線を示す。なお，SV は単位時間当たりの吸着材への通 液量を吸着材容積で除した值で定義する。模擬 HLLW を 吸着材容積の 5 倍 (5-bed volume) 通液した時点では，U, $\mathrm{Zr}$ のほか，MAの模擬物質である $\mathrm{Nd}$ や， Fe，Mo 等の元 素も吸着しているが，通液量の増加に伴い一度吸着した $\mathrm{Nd}$ や $\mathrm{Fe}, \mathrm{Mo}$ 等は， $\mathrm{U}, \mathrm{Zr}$ と置換して脱着し， U, Zr 以 外の吸着元素が吸着材から排出されるので, 最初の CMPO 含浸吸着材力ラム (第 1 吸着材) で U, Zr を HLLW から分離除去できる ${ }^{10,11)}$ 。第 1 吸着材に吸着した $\mathrm{U}, \mathrm{Zr}$ の溶離は $0.3 \mathrm{~mol} / \mathrm{dm}^{3}$ クエン酸 (以下，クエン酸溶離液) で可能である。Figure 3 に，模擬 HLLW による吸着お よびクエン酸による溶離処理を繰り返し行った時の $\mathrm{CMPO}$ 含浸吸着材への $\mathrm{U}, \mathrm{Zr}$ 吸着量の变化を示す。U の 吸着量はほぼ一定の值となり, Zr 吸着量はわずかに減少 傾向がみられるものの，7 サイクル目以降は初期の吸着容
量に対し $90 \%$ 程度の值で一定となり, 繰り返しによる吸 着容量の大きな変化は認められなかった。

第 1 吸着材を通過し U, Zr が除かれた HLLW は，後段 の第 2 CMPO 含浸吸着材カラム (第 2 吸着材) で MA やラ ンタノイド元素, Mo 等の FP 元素抢よび腐食生成物の $\mathrm{Fe}$ 等を吸着させ, $\mathrm{Cs}, \mathrm{Sr}$ 等と分離される。吸着した $\mathrm{MA}$ ・ ランタノイドの溶離には $0.01 \mathrm{~mol} / \mathrm{dm}^{3}$ 硝酸を使用する。 しかし，Mo 等はほとんど溶離できず，吸着材内に蓄積す る。Figure 4 に, 第 $2 \mathrm{CMPO}$ 含浸吸着材カラムにおける $\mathrm{Nd}, \mathrm{Mo}$ の吸着量と， $0.01 \mathrm{~mol} / \mathrm{dm}^{3}$ 硝酸による $\mathrm{Nd}$ と $\mathrm{Mo}$ の溶離率の変化を示す。吸着材を 3 回以上使用すると $\mathrm{Nd}$, Moいずれの吸着容量も徐々に低下する。この間 $\mathrm{Nd}$ は, ほぼ $100 \%$ 溶離するのに対し, Mo の溶離率は $5 \%$ 程度で あることから，この吸着容量の低下はMoの蓄積にあると 考えられる。Mo 以外では, Fe や白金族の一部も蓄積し た。これら蓄積元素の回収のため, 10 サイクル目と11サ イクル目に $0.5 \mathrm{~mol} / \mathrm{dm}^{3}$ シュウ酸と $0.01 \mathrm{~mol} / \mathrm{dm}^{3}$ 硝酸の 


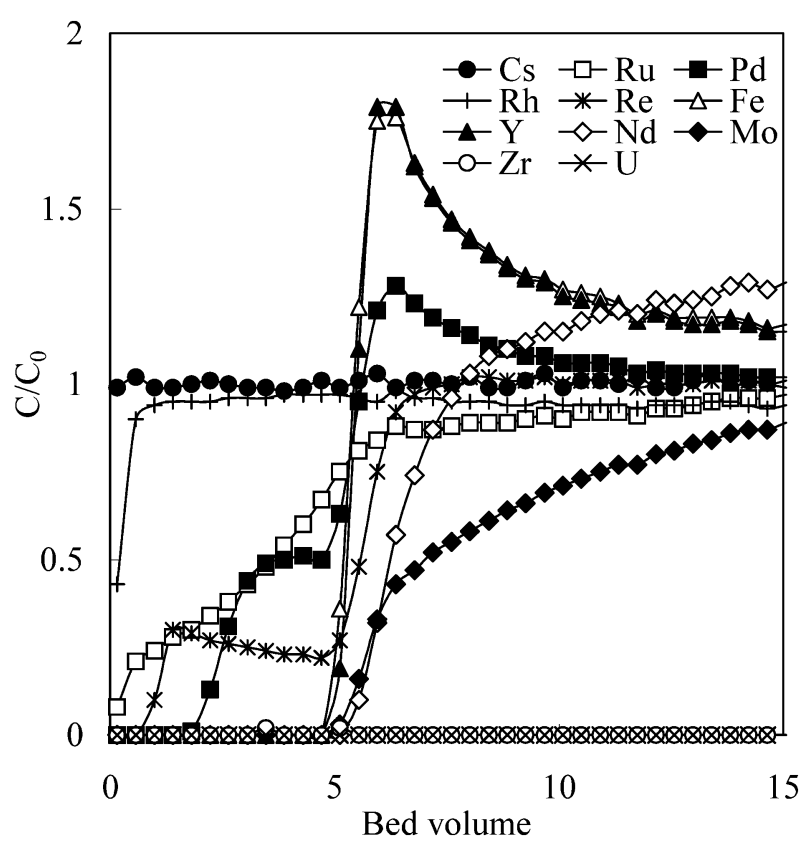

Fig. 2 Adsorption behavior of simulated HLLW with CMPOadsorbent

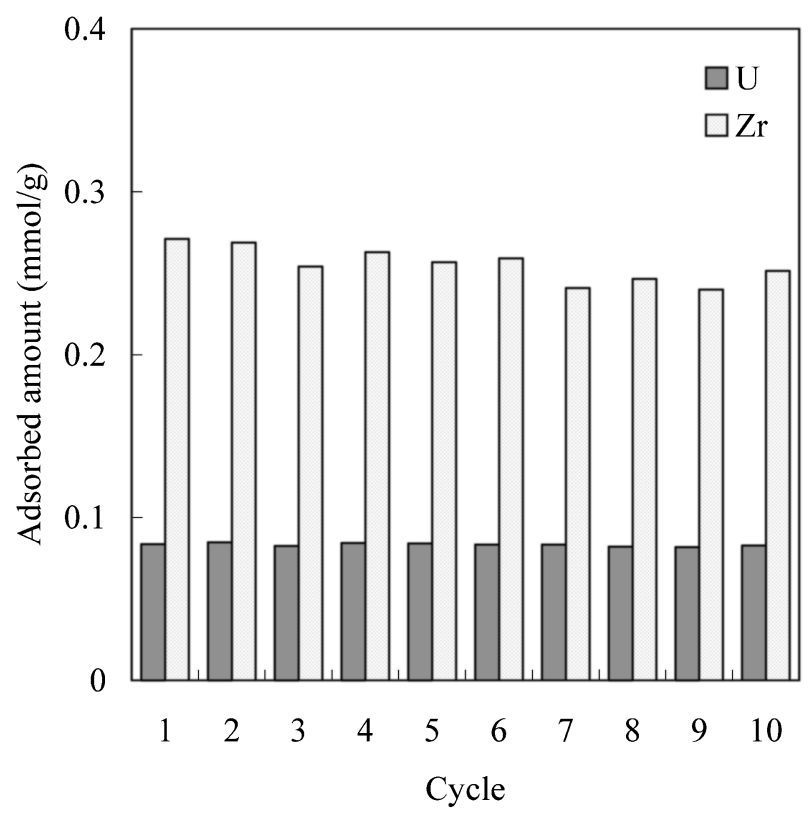

Fig. 3 Adsorbed amount of $\mathrm{U}$ and $\mathrm{Zr}$ with cycled treatment in first CMPO-adsorbent

混合溶液 (以下，シュウ酸溶離液)を通液したところ，10， 11サイクル目いずれもMo を始めとする蓄積元素がほぼ 100\%回収され，Nd，Mo 吸着容量はほぼ回復した。この 結果をもとに，蓄積した Mo の回収のために 3 サイクル に 1 回の頻度でシュウ酸溶離液を用いることにした。な お，この概念検討には含めていないが，必要に応じ分離さ れた MA・ランタノイドから，MAをチアカリックスア レーン含浸シリカ吸着材により回収することもできる17)。

さらに詳細は後述するが，クエン酸打よびシュウ酸溶離

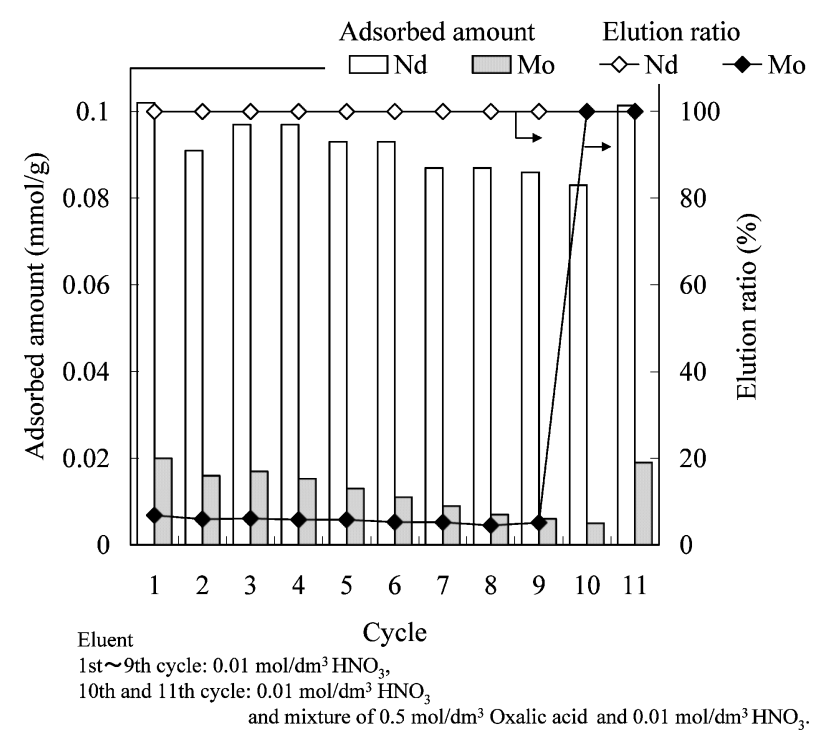

Fig. 4 Adsorbed amount of $\mathrm{Nd}$ and $\mathrm{Mo}$ and elution ratio of these elements with cycled treatment in second CMPO-adsorbent

液はその一部を再利用し，使用量の低減を図る。これらの 条件でプロセス概念検討を行った。

\section{III. 運 転 概 要}

第 $1 \mathrm{CMPO}$ 含浸吸着材カラムは吸着・溶離液を $\mathrm{SV}=$ 2.5/h で通液する。模擬 HLLW を使用した試験では，SV $=24 / \mathrm{h}$ までは吸着・溶離性に変化がないことを確認して いるので, SVは年間 $800 \mathrm{t}$ 再処理で発生する HLLW 量 を，年間200日運転で処理できる処理速度より大きくなる ように考慮した。U, Zr の溶離にはクエン酸を吸着材容積 の20倍 (20-bed volume) 通液する。なお，すべての吸着 · 溶離操作は $50^{\circ} \mathrm{C}$ で行うものとする。3 塔の吸着材力ラムは 交互に再生することで, 処理能力 $1 \mathrm{~m}^{3} / \mathrm{h}$ の濃縮機 2 台で 溶離液の濃縮処理に対応する。

第 $2 \mathrm{CMPO}$ 含浸吸着材カラムは, $\mathrm{SV}=3 / \mathrm{h}$ で吸着 ·溶 離処理する。 MA • ランタノイド等を吸着させ, Cs, Sr, 白金族元素廃液は通過液として回収される。溶離処理では $0.01 \mathrm{~mol} / \mathrm{dm}^{3}$ 硝酸を 5-bed volume 通液して, MA 等の 吸着元素を分離する。Moは 3 サイクルに 1 回シュウ酸溶 離液を 5-bed volume 通液して回収する。

\section{IV. 物 質 収 支}

\section{1. 核種分離工程の物質収支}

模擬 HLLW を使用した吸着 ·溶離試験の結果10,11) と $\gamma$ 線照射による吸着容量の低下10,12)を加味して, Table 1 に 示した核種の物質収支を検討した。Figure 5 に, 核種分 離工程のカラム通過液および各溶離液の核種の組成を示 す。な报， $\mathrm{Pu}$ と $\mathrm{Np}$ の吸着・溶離挙動は確認していない のでUと同じと仮定した。第 1 工程では, CMPO と親和 性の大きい, U, Zr を HLLW から吸着分離することが主 


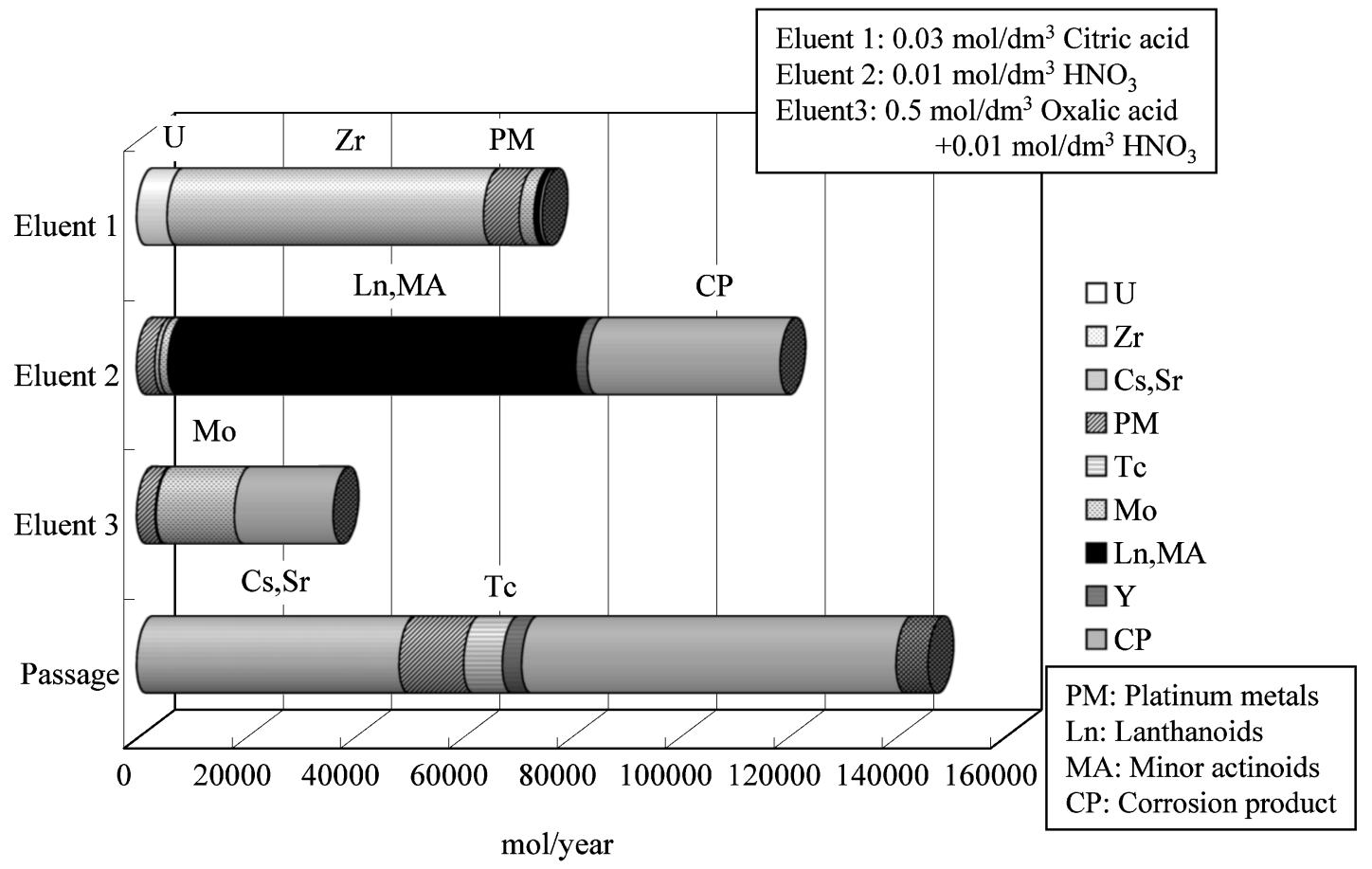

Fig. 5 Chemical composition of each solution from separation process

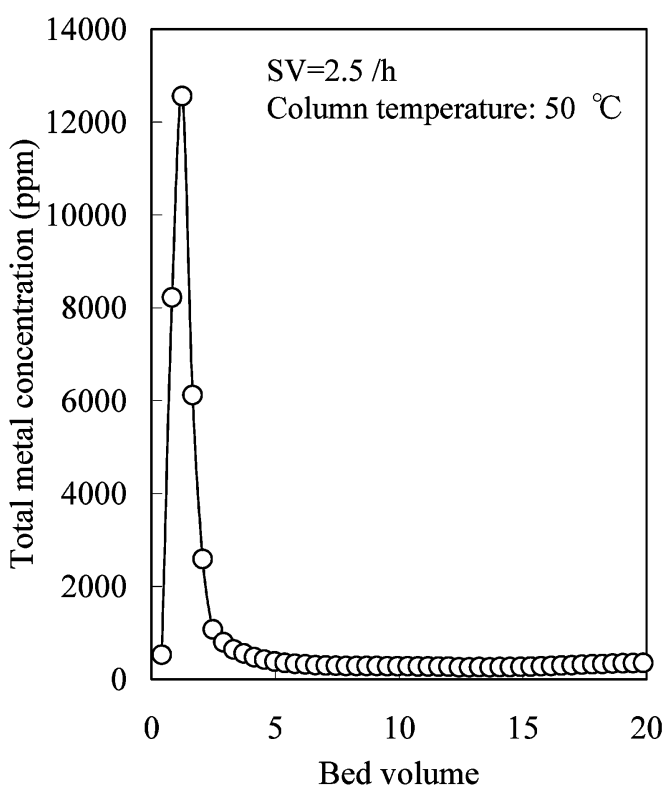

(a) Eluent: $0.03 \mathrm{~mol} / \mathrm{dm}^{3}$ citric acid

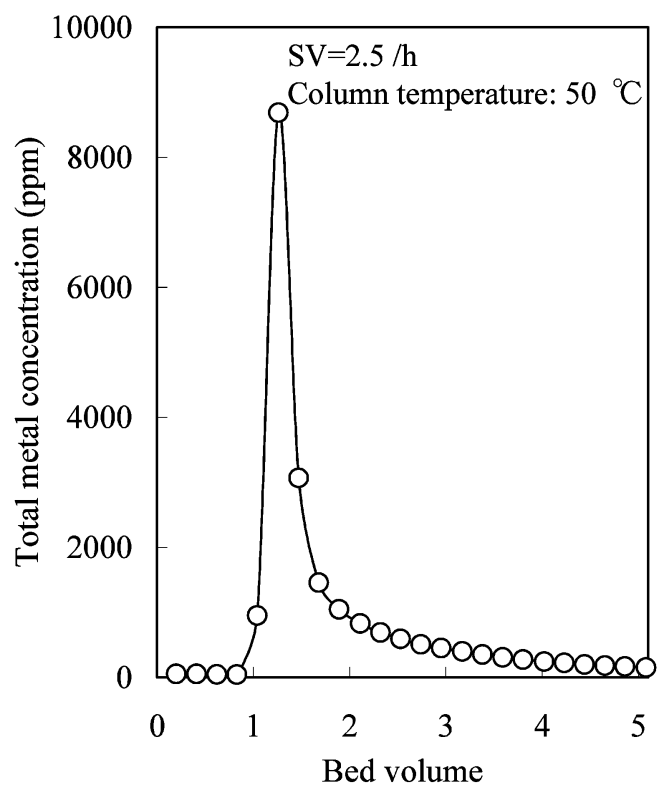

(b) Eluent: $0.5 \mathrm{~mol} / \mathrm{dm}^{3}$ Oxalic acid $+0.01 \mathrm{~mol} / \mathrm{dm}^{3} \mathrm{HNO}_{3}$

Fig. 6 Elution curve by using citric acid and oxalic acid

眼となる。ほぼすべての U, Zr と少量の白金族および Mo がカラムに吸着し, 他の元素群は通過して第 2 工程に送 られる。吸着した $\mathrm{U}, \mathrm{Zr}$ 等はクエン酸により溶離される (Eluent 1)。第 2 吸着材カラムを通過した液には高発熱 性核種である Cs, Sr が全量含まれ，また白金族元素の 約 $70 \%, \mathrm{Fe}$ 等の腐食性元素や $\mathrm{Y}$ 等の一部が含まれる (Passage)。Fe P Y は, 単独では CMPO 含浸吸着材へ相
当量吸着させることが可能であるが，MA・ランタノイド 等に比べ CMPO 含浸吸着材への吸着性が低いため, $\mathrm{MA}$ ・ ランタノイド共存下では, 一部が吸着されず通過液 側へ移行する。吸着元素群のうち, MA • ランタノイドは ほぼ全量が $0.01 \mathrm{~mol} / \mathrm{dm}^{3}$ 硝酸により溶離される (Eluent 2)。この溶液には吸着材へ吸着した一部の Fe, Y および $\mathrm{Pd}$ や $\mathrm{Ru}$ も含まれる。 $\mathrm{Pd}$ や $\mathrm{Ru}$ は, 硝酸溶液中で種々の 
化学形態を取るため, 通過液や各溶離液に分散してしまう。 Mo は約 $5 \%$ が $0.01 \mathrm{~mol} / \mathrm{dm}^{3}$ 硝酸溶離液に含まれる。0.01 $\mathrm{mol} / \mathrm{dm}^{3}$ 硝酸溶離液で溶離できない元素はシュウ酸溶離 液で回収される(Eluent 3)。

\section{2. クエン酸・シュウ酸溶離液の再利用 ${ }^{11)}$}

$\mathrm{U}, \mathrm{Zr}$ やMo を回收するために，大量のクエン酸やシュ ウ酸が必要となる。その量は，クエン酸で $3.5 \mathrm{t} / \mathrm{d}$ ，シュ ウ酸で $0.8 \mathrm{t} / \mathrm{d}$ と推定される。Figure 6 に, クエン酸, シ ュウ酸溶離液による, 全元素を合わせた溶離曲線を示す。 クエン酸溶離液の結果は, Fig. $6(\mathrm{a})$ に示す。クエン酸通 液後 1.2-bed volume で溶離金属濃度は最大となり, 吸着 した元素の約 $65 \%$ は，2.5-bed volume 分の通液で溶離し ている。残りの元素は，テーリング部分で回収される。こ のテーリング部分の全金属濃度は，500 ppm に満たな い。同様に，Fig. 6(b)に示すシュウ酸溶離液では，吸着 した元素の約 $75 \%$ が，2-bed volume 分の通液で溶離し， テーリング部分の全金属濃度は $1,000 \mathrm{ppm}$ 以下である。

金属濃度の低い，テーリング部分を溶離液として再利用 できれば，溶離に使用するクエン酸やシュウ酸の量を低減 できる。クエン酸溶離液の75\%（5-bed volume 以降の溶 離液) 抢よびシュウ酸溶離液の $60 \%$ (2-bed volume 以降の 溶離液)を再利用した場合の，再利用回数と 1 日当たりの クエン酸，シュウ酸使用量の関係を Fig. 7 に示す。溶離 液を 1 回再使用する，すなわち溶離液を 2 度使用するこ とで, クエン酸使用量は 1 日当たり $3.5 \mathrm{t}$ から $2.2 \mathrm{t}$ まで低 減できる。さらに 2 回再使用 (計 3 度使用)した場合, ク
エン酸使用量は 1 日当たり約 $1.8 \mathrm{t}$ となり, 再利用しない 場合と比較し半減できる。同様にシュウ酸使用量は 1 回 再利用で $0.6 \mathrm{t} / \mathrm{d}, 2$ 回再利用で $0.5 \mathrm{t} / \mathrm{d}$ となり, 再利用し ない場合 $(0.8 \mathrm{t} / \mathrm{d})$ の約 $60 \%$ となる。しかし，いずれの溶 離液も再使用回数をこれ以上に増やすと低減効果は小さく なる。

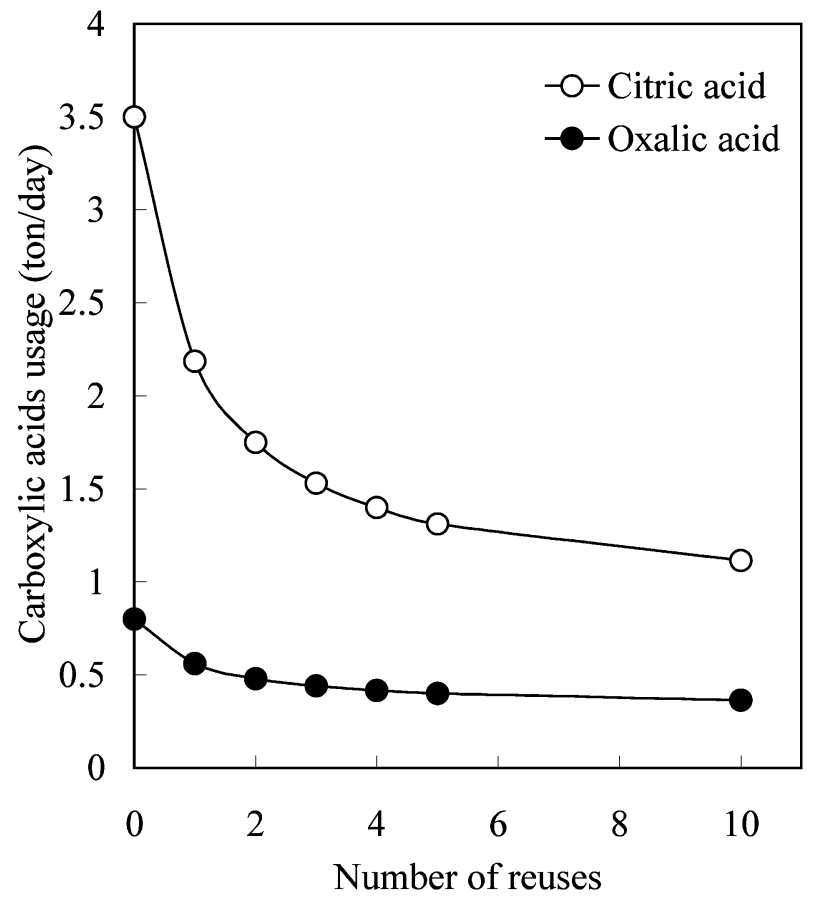

Fig. 7 Effect of eluents reuse on citric acid and oxalic acid usage

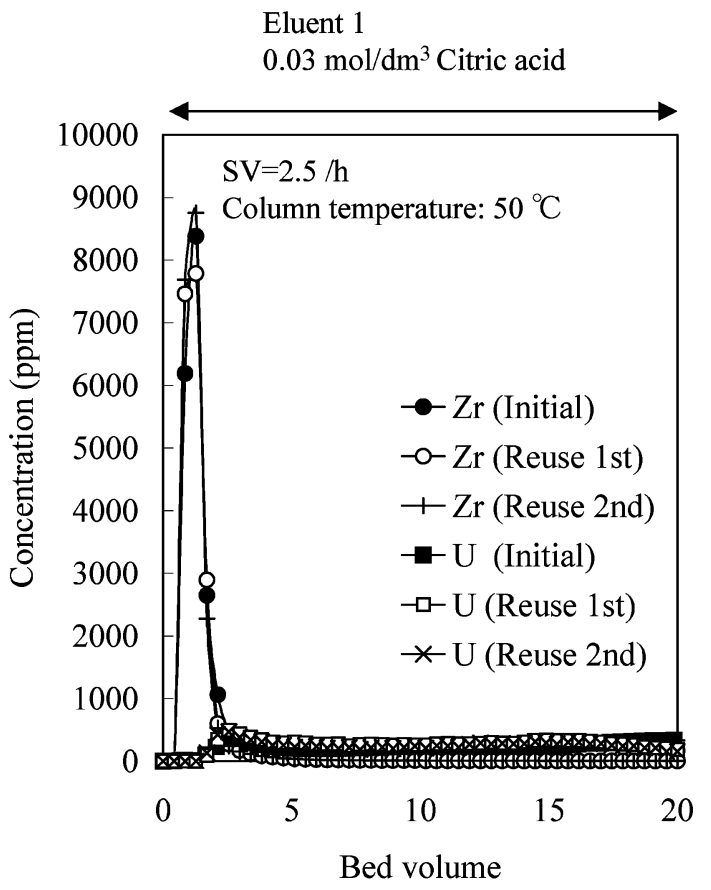

(a) Elution behavior with 1st column

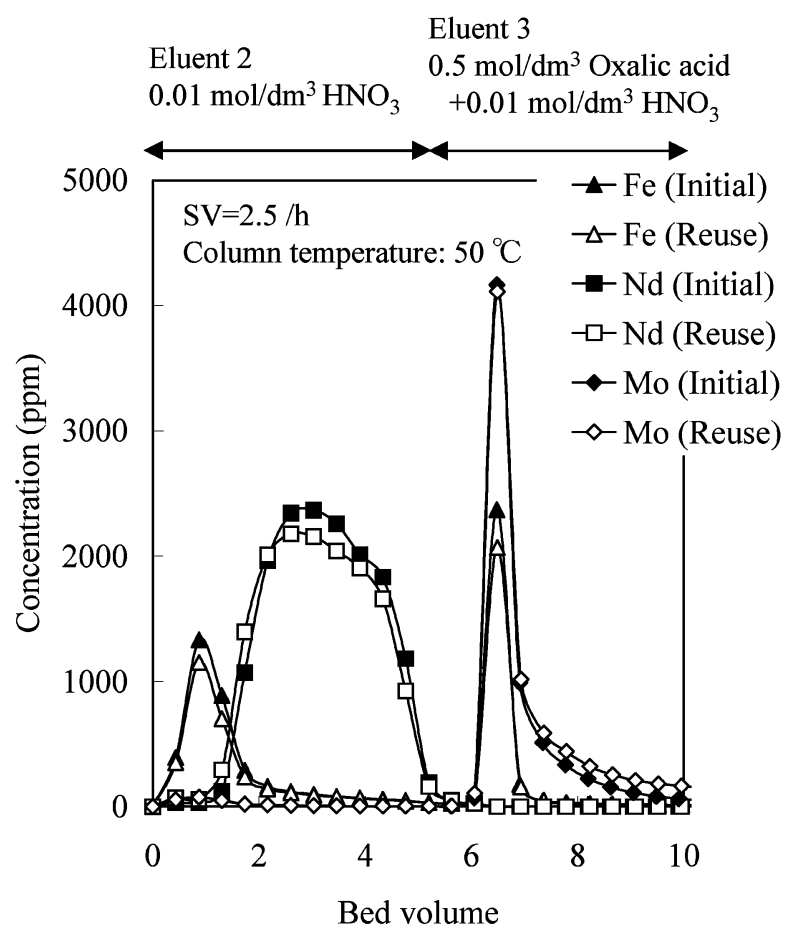

(b) Elution behavior with 2nd column

Fig. 8 Elution curves of various elements with reused eluents 
Figure 8 に, 使用済みクエン酸およびシュウ酸溶離液 のテーリング部分を再利用した時の溶離曲線を示す。この 際，再利用する溶離液はテーリング部分だけなので必要な 溶離液量が不足する。この不足分は新たな溶離液と，再利 用する溶離液を混合して使用した。Figure 8(a)には，ク エン酸溶離液再利用の結果を示す。最初と 1 回および 2 回の再利用における $\mathrm{U}, \mathrm{Zr}$ 溶離曲線はほぼ一致した。

Figure 8 (b) は, 第 $2 \mathrm{CMPO}$ 含浸吸着材を想定した溶離試 験の結果である。 $\mathrm{Nd}$ 等の溶離には $0.01 \mathrm{~mol} / \mathrm{dm}^{3}$ 硝酸を 再利用せずに使用し，Mo 等の溶離に際してシュウ酸を再 使用したが，初回と再利用時の溶離曲線はほとんど一致し ており, クエン酸，シュウ酸ともに再利用が可能であるこ とがわかる。

前述のように溶離液は CMPO で飽和させるが，この溶 離液中の CMPO は吸着材と相互作用することなしに, 溶 離液中に溶存していると考えられる。各溶離液に対する $\mathrm{CMPO}$ 溶解量はリン換算で約 $20 \mathrm{ppm}$ である。クエン酸 およびシュウ酸溶離液を 2 回再利用(計 3 度使用)した場 合の各溶離液の使用量は, クエン酸溶離液 (Eluent 1) で $6,100 \mathrm{~m}^{3} / \mathrm{y}, 0.01 \mathrm{~mol} / \mathrm{dm}^{3}$ 硝酸溶離液 (Eluent 2) で 10,770 $\mathrm{m}^{3} / \mathrm{y}$ ，シュウ酸溶離液 (Eluent 3 ) で $2,145 \mathrm{~m}^{3} / \mathrm{y}$ であるの で, 各溶離液に含まれる $\mathrm{CMPO}$ 由来のリンの量は，それ ぞれ $122 \mathrm{~kg} / \mathrm{y}, 215 \mathrm{~kg} / \mathrm{y}, 43 \mathrm{~kg} / \mathrm{y}$ となる。

\section{V. 吸着材寿命}

\section{1. 廃吸着材発生量}

CMPO 含浸吸着材は， $\gamma$ 線照射線量の増加に伴いオク チルフェニルホスフィン酸 $(\mathrm{OPP})$ を経由してリン酸に分 解し, 照射線量 $2 \mathrm{MGy}$ 付近での MA • ランタノイドの吸 着容量は初期吸着容量の約 $80 \%$ ，U の吸着容量は約 $85 \%$ にまで低下する ${ }^{10,12)}$ 。この，照射線量が $2 \mathrm{MGy}$ に達した 時点で吸着材を交換すると, 吸着・溶離処理可能回数抢よ び廃吸着材発生量は, 1 処理当たりの照射線量で決まる。 1 処理当たりの照射線量は，線量率と処理時間すなわち SV に依存するので，SV と廃吸着材発生量の関係を調べ た。廃吸着材発生量推定のベースとなる吸着処理時の線量 率は, HLLW の発熱量から計算した。具体的には ORIGEN II 計算コードをもとに，1 MTU 当たりの核種の発 熱量を推定し $(2,800 \mathrm{~W} / \mathrm{MTU}) ，$ ここからU 濃度を 1 $\mathrm{mol} / \mathrm{dm}^{3}$ と仮定した $\mathrm{SF}$ 溶解液の $\mathrm{U}, \mathrm{Pu}$ を除く核種発熱 量を計算し $\left(0.66 \mathrm{~W} / \mathrm{dm}^{3}\right), 1 \mathrm{Wh} / \mathrm{dm}^{3}=3,600 \mathrm{~Gy}$ である ので HLLW の 1 時間当たりの線量率は $2,400 \mathrm{~Gy} / \mathrm{h}$ と推 算した。溶離時の線量率は，第 $1 \mathrm{CMPO}$ 含浸吸着材では 吸着核種が U と Z r であり発熱量はほとんど無視できるの で 0 とした $(\mathrm{CMPO}$ の分解の主原因は，水や硝酸が $\gamma$ 線に より分解して生成したラジカルによると推定し， $\alpha$ 線の影 響は考慮しなかった)。第 $2 \mathrm{CMPO}$ 含浸吸着材では，吸着 処理時の線量率は $2,400 \mathrm{~Gy} / \mathrm{h}, \mathrm{MA}$ ・ランタノイド溶離で の線量率は，Cs, Sr，白金族元素が除去されているので

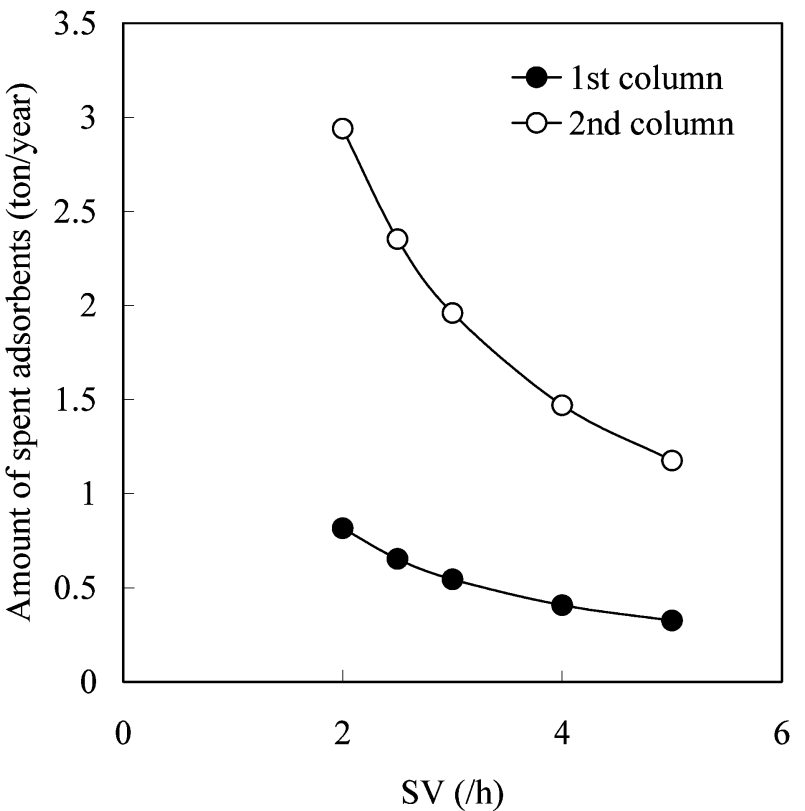

Fig. 9 Effect of space velocity on amount of spent adsorbents

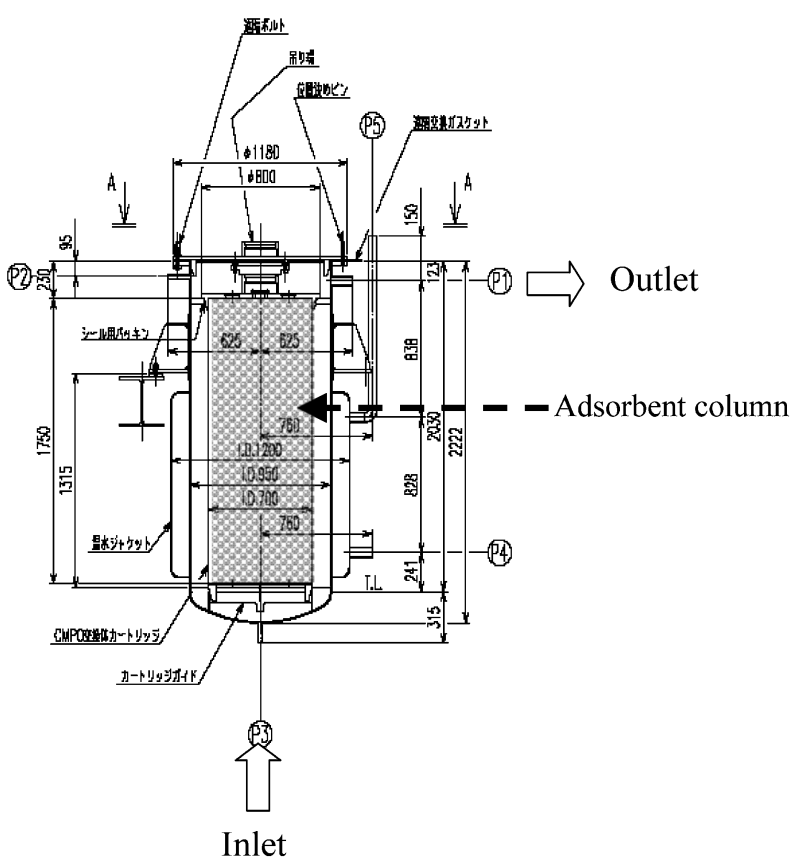

Fig. 10 Outline drawings of adsorption cartridge

$920 \mathrm{~Gy} / \mathrm{h}, \mathrm{Mo}$ 溶離での線量率は $\mathrm{Cs}, \mathrm{Sr}$ 等のほかに $\mathrm{MA}$ ・ ランタノイドも除去されているので $440 \mathrm{~Gy} / \mathrm{h}$ と推 定した。これらをもとにしたSV と廃吸着材発生量の関係 をFig. 9 に示す。SVが大きいほど 1 処理当たりの照射 線量が低下するので, より多くの吸着・溶離処理を行うこ とが可能となり廃吸着材量が減少する。第 2 カラムから の廃吸着材量が多いのは, 溶離処理時の照射線量が第 1 カラムより大きいためである。ここでは, 吸着・溶離処理 に扣いて第 $1 \mathrm{CMPO}$ 含浸吸着材の SVは $2.5 / \mathrm{h}$, 第 2 CMPO 含浸吸着材では $3 / \mathrm{h}$ に設定したので，第 1 カラム 
からの廃吸着材発生量は $0.7 \mathrm{t} / \mathrm{y}$, 第 2 カラムからは $2 \mathrm{t} / \mathrm{y}$ となり, 総廃吸着材発生量は年 $2.7 \mathrm{t}$ と推算される。

\section{2. 吸着材の交換方法}

劣化した CMPO 含浸吸着材は，新規吸着材に取り替え る必要がある。その交換方法として，カートリッジ方式を 検討した。カートリッジ式カラムはカートリッジ部分とこ れを収容する収納容器部分から構成される(Fig. 10)。 カートリッジサイズは, CMPO 含浸吸着材の必要容量, 空間速度，圧損およびカートリッジ交換時のハンドリング 性を考慮し, $700 \mathrm{~mm} \phi \times 1,750 \mathrm{~mm}$ (内容積 $0.67 \mathrm{~m}^{3}$ ) とし た。この CMPO 含浸吸着材では, 通液線速約 $12 \mathrm{~cm} / \mathrm{min}$ までほとんど圧力損失が生じない（直径 $10 \mathrm{~mm} \phi \times$ 高さ $500 \mathrm{~mm}$ カラムによる小規模試験の結果) が，カートリッ
ジ径が 700 mmфであれば $\mathrm{SV}=2.5 \sim 3 / \mathrm{h}$ の範囲で線速は $7 \sim 9 \mathrm{~cm} / \mathrm{min}$ にできるので, カートリッジ方式での運転 は可能であると考えられる。カラム本体の大きさはカート リッジを収容でき, 遠隔操作取り出しに十分な空間のある $950 \mathrm{~mm} \phi \times 2,222 \mathrm{~mm}$ とした。CMPO 含浸吸着材内での 通液偏流を避けるため, カラム下部から液を供給し, カラ ム上部からオーバーフローさせる構造とし, カラム内部の 液温を $50^{\circ} \mathrm{C} に$ 保持するために外側に温水ジャケットを設 ける構造とした。

\section{VI. 分離工程の建屋空間内の配置概念}

以上の結果をもとに分離工程の建屋空間内の配置概念を 検討した。Figure 11 に，2 階平面配置概念図と断面図を 示す。な抢，検討に当たっては， C4 セル-C4 セル間， C4

Plain view (Second floor)

$80 \mathrm{~m}$

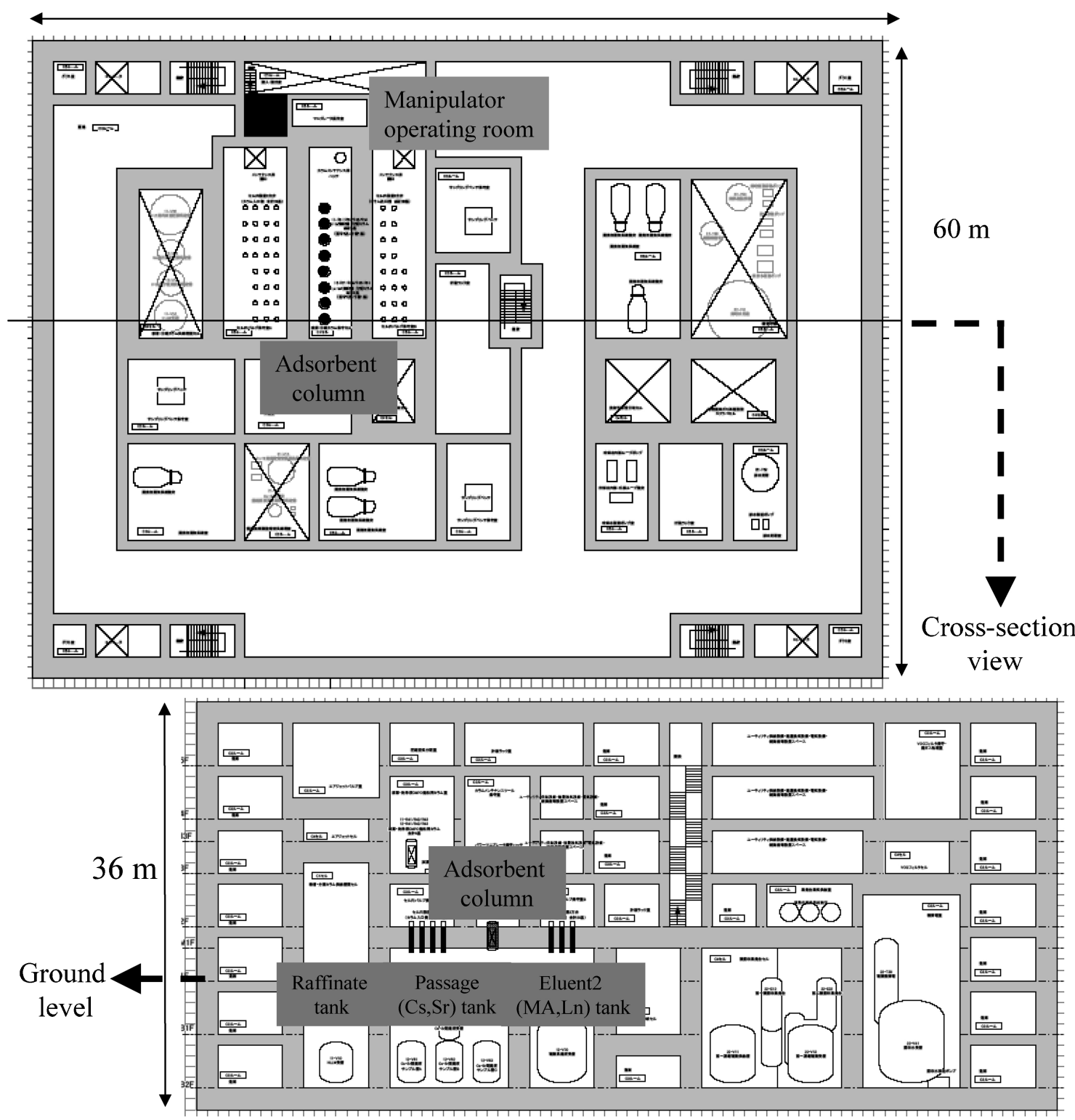

Fig. 11 Plot plan drawing around adsorbent column 
セル-C3 ルーム間の床および壁厚は $2 \mathrm{~m}$ とし, C3 以下 ルームールーム間の床および壁厚は $1 \mathrm{~m}$ とした。また， ユーティリティ(冷却水, 蒸気, 圧縮空気, 温水等)は建屋 外から適宜供給されるものとし, 本建屋内はユーティリテ ィを分配するための設備の久設置するものとした。高放射 能廃液移送には土アジェットサイフォン方式を, カラムへ の供給液, 溶離液洗浄液の切り換えはバルブフィード方式 を適用した。建屋内の設備配置は, 上層階に溶離溶離液等 の試薬供給設備, 2 階に第 1 , 第 2 吸着設備の両方を配置 し，着材カラムの搬入・搬出は，マニピュレーターを用い て 1 階を経由して行われるものとした。なお，第 1 , 第 2 CMPO 含浸吸着材カラムともに充填量は $0.67 \mathrm{~m}^{3}(0.33 \mathrm{t})$ で, 予備カラムを 1 塔ずつ設け, 計 8 塔設置する。廃液 濃縮工程関連設備は地下階に配置される。建屋規格は概略 縦 $60 \mathrm{~m} \times$ 横 $80 \mathrm{~m} \times$ 高さ $36 \mathrm{~m}$ (地上 5 階, 地下 2 階)の施 設になった。

\section{VII. 結言}

CMPO 含浸吸着材を使用した吸着 ·溶離繰り返し試験 の結果および $\gamma$ 線照射試験の結果をもとに高レベル放射性 廃棄物固化体発生量を低減するため核種分離プロセス概念 について検討した。また, 溶離液処理の方法や使用済久吸 着材の発生量, 吸着材カラム交換方法に, さらに主要設備 の配置および規模ついて検討した。

本研究は, 経済産業省資源エネルギ一庁からの委託調査 事業である「地層処分技術調査等(処理技術高度化調査)」 の一環として, 平成 12 年度から平成 16 年度にかけて実施 した研究成果に基づくものであり，ご協力いただいた関係 各位に対して謝意を表します。

\section{一参考文献一}

1）藤田朝雄, 清水和彦, “高レベル放射性廃棄物地層処分の工 学技術,”資源と素材，117[10], 794 (2001).

2）田川博彰, “高レベル放射性廃棄物固定化に関する研究：I, ” 横浜国大環境研紀要, 8, 89 (1982).

3) L. L. Hench, D. E. Clark, A. B. Harker, "Review nuclear waste solids," J. Mater. Sci., 21, 1457 (1986).

4) H. Ohtsuka, K. Suzuki, "A relation between high loading of
HLW and space reduction of disposal," Proc. GLOBAL 2005, Tsukuba, Japan, Oct. 9-13, 2005 Paper No. 499 (2005).

5）森田泰治, 館盛勝一, 駒 義和, 他, 高レベル廃液からのア クチニド分離プロセスの研究, JAERI-RESEARCH-2002017 (2002).

6) T. Takata, Y. Koma, K. Sato et. al., "Conceptual desighn study on advanced aqueous reprocessing system for fast reactor fuel cycle," J. Nucl. Sci. Technol., 41[3], 307 (2004).

7) Y.-Z. Wei, M. Kumagai, Y. Takashima et al., "Studies on the separation of minor actinides from high-level waste by extraction chromatography using novel silica-based extraction resins," Nucl. Technol., 132, 413 (2000).

8）韋 悦周, 駒 義和, 新井 剛, 他, “シリカ担持型 CMPO 吸 着材の基礎特性に関する試験研究, ” 日本原子力学会和文論 文誌， 1[4]，432（2002）。

9）駒 義和, 高田 岳, 佐藤浩司, “先進湿式再処理プラントの 概念検討(1)-MAREC 法による Am 及び Cm の回収, ”日本 原子力学会「2004年春の年会」要旨集, F50 (2002).

10) T. Kikuchi, I. Goto, K. Suzuki, "Separation of heat release nuclides in HLW by CMPO impregnated silica ion-exchanger," Proc. 9th Int. Conf. on Radioactive Waste Management and Environmental Remediation, Oxford, UK, Sept. 2125, 2003, Paper No. ICEM03-4635 (2003).

11) I. Goto, T. Kikuchi, K. Suzuki, "Partitioning of HLLW by CMPO impregnated silica adsorbent," Proc. GLOBAL 2005, Tsukuba, Japan, Oct. 9-13, 2005, Paper No. 409 (2005).

12) T. Kikuchi, I. Goto, K. Maruyama et al., "Durability of CMPO impregnated silica adsorbent under irradiation conditions," $J$. Nucl. Sci. Technol., 43[5], 562 (2006).

13) J. N. Mathur, M. S. Murali, P. B. Ruikar et al., "Degradation, cleanup, and reusability of octilphnyl- $N-N^{\prime}$-diisobutylcarbamolymethyl phosphine oxide (CMPO) during partitioning of minor actinides from high level waste (HLW) solutions," Sep. Sci. Technol., 33[14], 2179 (1998).

14) M. Benedict, T. H. Pigford, H. W. Levi, 原子力化学工学第 IV 分冊 燃料再処理と放射性廃棄物管理の化学工学, 日刊工 業新聞社, 61, 168 (1983).

15）日本原燃編, “再処理施設に抢ける放射性核種の挙動, ” JNFS R-91-001改 1, 15, 18 (1996).

16）塚田毅志, 高橋恵樹, L. Koch, 他, PUREX 再処理条件下 に打ける高燃焼度 $\mathrm{UO}_{2}$ 燃料抢よび MOX 燃料の溶解特性, 電力中央研究所狛江研究所研究報告, T97082, 71 (1998).

17) T. Kikuchi, I. Goto, K. Suzuki, "Effect of irradiation on adsorption performance of Thiacalix [4] arene impregnated silica adsorbent," J. Nucl. Sci. Technol., 43[6], 690 (2006). 